TEME, г. XLI, бр. 3, јул - септембар 2017, стр. 587-606

Претходно саопштење

DOI: $10.22190 /$ TEME1703587J

Примљено: 13. 1. 2017.

UDK 37.017.92-053.6

Ревидирана верзија: 9. 4. 2017.

Одобрено за штампу: 15. 6. 2017.

\title{
SCHOOL INDICATORS OF ENCOURAGING HUMANISTIC EDUCATION OF ADOLESCENTS
}

\author{
Bisera Jevtić, Marija Jovanović \\ University of Niš, Faculty of Philosophy, Department of Pedagogy, Niš, Serbia \\ *bisera@vaspks.edu.rs
}

\begin{abstract}
Encouragement of humanistic education through the lens of prosocial behavior of adolescents is a complex and extensive issue of the modern world. Prosocial behaviour can indirectly affect the achievement of pupils at school through its connection with some academically relevant forms of behaviour which lead to success at school and work. Also, this connection can be explained by the teacher's preferences of prosocial pupils, which is reflected in the teacher's expectations and behaviour towards pupils, as well as the evaluation of their work. Besides, prosocial behaviour can also directly affect pupils since the prosocial interaction of peers can have a positive effect on the intellectual exchanges between pupils, which contributes to a more successful learning process. Taking into consideration the significance and role of the school and teachers, as representatives of the educational process, in encouraging prosocial behaviour in the young at secondary schools, we face a problem: Do secondary school teachers encourage prosocial humanistic behaviour of the young, by what actions and activities are they guided in the process and how does that reflect on the behaviour of pupils? This study tried to give some answers related to this problem in the field of education.
\end{abstract}

Key words: humanistic education, prosocial behaviour, moral pedagogy, teachers, achievement.

\section{ШКОЛСКИ ПОКАЗАТЕЉИ ПОДСТИЦАЫА ХУМАНИСТИЧКОГ ВАСПИТАЫА АДОЛЕСЦЕНАТА}

\begin{abstract}
Апстракт
Подстицање хуманистичког васпитања кроз призму просоцијалног понашања адолесцената представља сложену и широку проблематику данашњице. Просоцијално понашање може индиректно утицати на школско постигнуће ученика, и то тако што је повезано са одређеним академски релевантним облицима понашања која воде постизању успеха у учењу и раду. Такође, повезаност се објашњава посредством наставникових преференција просоцијалних ученика, што се одражава на наставникова очекивања и понашање према ученицима, али и вредновање њиховог рада. Поред тога, могуће је и директно деловање просоцијалног понашања, јер се просоцијалним интеракцијама вршњака остварује позитивна интелектуална размена међу
\end{abstract}


њима, што доприноси успешнијем савладавању наставног градива. Разматрајући значај и улогу школе и наставника као представника васпитно-образовног процеса у подстицању просоцијалног хуманистичког понашања младих у средњим школама, намеће се следећи проблем: Да ли наставници у средњим школама подстичу просоцијално хуманистичко понашање младих, којим се поступцима и активностима притом руководе и како се то одражава на понашање ученика? Овај рад нам нуди одговоре у вези са наведеним проблемом у образовању.

Кључне речи: хуманистичко васпитање, просоцијално понашање, педагогија моралности, наставници, постигнуће.

\section{INTRODUCTION}

Examining the social context in which we currently live, we can observe a paradox. Namely, on one hand, the socio-political turmoil that a society in transition has to go through produces a disturbed value system, a moral crisis, apathy, hopelessness, aggression and different forms of intolerance, which can be an obstacle to the development and encouragement of prosocial behaviour in young people. On the other hand, positive behaviors such as prosocial behavior, altruism and empathy are most needed in difficult times, which show examples of solidarity in exceptional circumstances (Jevtić, 2015.)

Prosocial behaviour is a broad construct, related to different phenomena. "The elements of social behaviour are often an imminent part of some other constructs, such as 'peer acceptance' and 'social competence'. The school, an institution which educates the young, should not neglect the area of prosocial behaviour " (Jevtić, 2017, p. 34). However, a question should be asked: To what extent does the school contribute in an organized way to the encouragement and development of the prosocial behaviour of pupils?

Regarding the axiological dimension which prosocial behaviour has in the process of the personality formation of the young in the sense of their achieving general competence and regarding the role that teachers as educators have in the process, dealing with this issue can contribute to its becoming more significant. Prosocial behaviour can indirectly affect the achievement of pupils at school through its connection with some academically relevant forms of behaviour which lead to success at school and work. Also, this connection can be explained by the teacher's preferences of prosocial pupils, which is reflected in the teacher's expectations and behaviour towards pupils, as well as the evaluation of their work. Besides, prosocial behaviour can also directly affect pupils since the prosocial interaction of peers can have a positive effect on the intellectual exchanges between pupils, which contributes to a more successful learning process. 


\section{Theoretical Clarifications of the Basic Terms in the Study}

People are social beings who prefer living in social groups and a cultural framework, so "most cultures encourage and even require prosocial behaviour because it is vital to the system" (Twenge et al, 2007, p. 56). "Prosocial behaviour is a constant of every human being. It is a component of a human being's essence. It is the readiness and ability to accept and understand others as well as doing something for others regardless of the award. Its deep human, emotional and moral intentions are in accord with love which aims at doing good to the other" (Žilinek, 1997, p. 131). Prosocial behaviour represents the core of human relationships because "one of the most important aspects of humans, distinguishing us from other species, is the degree of helping, cooperation, and altruism among people" (Knafo \& Plomin, 2006, p. 771).

Judging from various definitions of prosocial behaviour, it turns out that this term entails a wide range of behaviour: from the absence of negative behaviour through behaviour directed at the welfare of others, including a possible welfare of oneself, to altruistic behaviour which aims at others' welfare without any expectations of personal benefit (Staub, 1978; Eisenberg \& Mussen, 1989). Some authors use the term 'prosocial behaviour' and 'altruistic behaviour' as synonyms, while others make a distinction considering 'altruism' a narrower term. Actually, the latter talk about altruism only if it is a selfless act performed with the aim of contributing to the benefit of the other, without a conscious expectation of personal benefit. In that case, prosocial behaviour is a broader term since it does not necessarily exclude the behaviour accompanied by achieving some personal or mutual material or social benefit (Joksimović \& Vasović, 1990). Motives for prosocial behaviour can be various: one motive can be a genuine wish to help someone, or an attempt to receive some reward (acclaim of the surroundings, a rise of self-esteem) or to avoid penalty (social criticism, a sense of guilt). There are also different solutions for the operationalisation of prosocial behaviour. As forms of prosocial behaviour, Bar-Tal and Raviv (1982) mention helping, cooperation and exchange. Different forms of prosocial behaviour are also mentioned by Vispe (in Joksimović and Vasović, 1990), who includes altruism, compassion, cooperation, giving gifts and helping. Empirical research shows that there is a great variety when it comes to the choice of indicators of prosocial behaviour. Bearing in mind that this is a complex phenomenon, it is not surprising that researchers often focus on discrete, narrower segments of prosocial behaviour, which makes the process of comparing and generalizing their findings more difficult.

Empathy has been defined both as laying the foundations for prosocial development and as a mechanism of social influence on social behaviour. Quite a few theoretical frameworks, including psychoanalytic theory, social learning theory and social cognition theory, socialisation, and the 
development of empathy and prosocial behaviour (Eisenberg \& Valiente, 2002; Grusec, Davidov, \& Lundell, 2002).

Alternative ways of control through emotional manipulation (such as disapproval or withholding love) are not believed to be tightly linked with the internalisation of prosocial values, although others do suggest that these can promote reparatory prosocial acts after a transgression by making the person feel guilty (Zahn-Waxler \& Kochanska, 1990).

Another term which can be linked with the term 'prosocial behaviour' is promethean activism, "which reflects in the aspiration to influence one's own fate actively, to control events in the social surroundings and society in general, to change the existing state and to persist in that despite obstacles, to take risks and responsibility" (Joksimović, 1993, p. 75). Thus defined, promethean activism represents a broader value orientation and disposition which, among other activities, can affect prosocial behaviour, too. "However, while extreme promethean activism can entail engaging in the situations when chances for success are slim and which can be evaluated as dangerous and risky, the indicators of prosocial behaviour predominantly include helping in everyday situations which do not require great risk or sacrifice, so certain forms of helping are encouraged by social norms and etiquette" (Ibidem, 1993, p. 75). To understand the phenomenon of prosocial behaviour fully, it is necessary to mention the problem of motivating prosocial behaviour. Motivation for prosocial behaviour can be various. A person can exhibit prosocial behaviour because "he/she may expect rewards or reciprocity, may fear repercussions for not being prosocial, or mainly want to alleviate another's distress. Displays of concern for others may occur in the form of proactive efforts to prevent another coming to harm, spontaneous reactions to witnessed events, reparative actions after having been the cause of some distress to another, or compliant responses to directives or solicitations for assistance" (Hastings, Utendale \& Sullivan, 2007 , p. 639). That empathy is a precursor of and a motivation for prosocial behaviour and is emphasized by the theoretician De Waal. "De Waal (2008) proposed that empathy is an evolved mechanism that promotes altruistic behaviour. If a person sees someone in distress, for example, he may himself begin to feel distressed; this would provide a strong internal signal that the other person needs help.

At that point, the feeling of distress may lead the person to think of what might make him feel better in similar situations, which may then promote helping behaviour." (McDonald \& Messinger, 2010, p. 17).

Regarding the problem of motivation for altruistic behaviour "Karylowski (1982) distinguishes between exocentrically motivated altruism which is mostly directed at the person who receives help or support, and endocentrically motivated altruism which is connected with the expectation of inner reward (self-satisfaction or self-importance) or inner punishment (for example, a sense of guilt or shame due to the absence of altruistic behaviour). To a much larger extent, selflessness is a characteristic of exocentrically motivated rather than endocentrically motivated altruism" 
(Lobocki, 1997, p. 114). Eisenberg (in Kakavulis, 1997) believes that altruistic behaviour can be motivated by amoral motives (a wish for social approval), or even by immoral motives, such as a wish to manipulate others for the sake of one's own benefit.

Batson $(2008$, p. 3) defines altruism "as a motivational state whose ultimate end is the improvement of someone else's welfare". Altruism is contrasted with egotism, i.e. the motivational state which has the improvement of one's own welfare for its ultimate aim. Although these represent two extremes, altruism and egotism are actually rather similar. "Both refer to the motivational state, both deal with the final aim of that state and each has the improvement of someone's welfare as its end. The characteristics they have in common emphasise the key difference: whose welfare is the ultimate end, someone else's or ours?" (Batson, \& Shaw, 1991, p. 108).

\section{Research on School Indicators of Motivating Prosocial Behavior}

In Studies (Jevtić, 2017) show that there is a positive connection between pupils' prosocial behaviour and school achievement. To shed light on the relationship between prosocial behaviour and school achievement, a study has been carried out to determine: (a) what is the relationship between prosocial and academic success considering a possible impact of the accompanying effect of academically oriented forms of behaviour in class; (b) what is the role of the teacher's preferences in that relationship, and (c) does prosocial behaviour represent a direct, independent predictor of school achievement (Wentzel, 1993). Data on prosocial behaviour are obtained through peer and the teacher's evaluation of the behaviour in question (a pupil shares and cooperates, helps other pupils when they have a problem). It has also been confirmed that prosocial behaviour mediates between school achievement, on one hand, and interpersonal and selfregulatory aspects of social competence, on the other (Wentzel, 1991). However, self-regulatory processes can also explain a considerable interrelatedness between prosocial behaviour, peer acceptance and control variables to a large extent. Within a wider study aiming at analyzing psychosocial mediators of school success, the role of prosocial behaviour was included too (Bandura et al., 1996). It was found that prosocial orientation plays a significant role in achieving school success both directly and indirectly, influencing peer acceptance, a lower degree of depression, moral judgement and problematic behaviour, each of which individually affects the variable of academic achievement.

Studies which have examined the relationship between pupils' social competence or social skills and academic achievement indicate a positive correlation of these variables (Rotheram, 1987; Chen, Rubin, \& $\mathrm{Li}$, 1997). The instruments to examine social skills include different forms of pupils' prosocial behaviour, classified into certain clusters of social skills (for example: cooperation, assertiveness, responsibility, empathy, 
self-control). The situations in which prosocial, altruistic behaviour is examined are rather simple and distant from real life circumstances.

Within social cognitive theory, researchers (Fabes, Fultz, Eisenberg, May-Plumlee \& Christopher, 1989) investigated the influence of causal attributions, finding that the young were more prosocial when their acts were ascribed to internal motivations or characteristics than when they were ascribed to external pressures or rewards (in Hastings, Utendale, Sullivan, 2007).

These studies provide proof of the internalisation or long-term effects of socialisation emerging from short learning experiences. Manipulating social potentials can change prosocial behaviour of the young, but the effects are not universal.

Educational means are applied in a specific way, so their application by different subjects has a great significance for the moral development of a person. To develop and form the moral personality in children and the young, it is necessary for education to develop their ability to use and understand cultural rules, needs, expectations and meanings in all components of competencies: in cognitive, emotional, social and action ones. Starting from the current educational actions of encouraging which are applied in education, we have classified educational actions according to the definitions of terms, their application and significance; this has helped us to present the structure of encouragement and gain an insight into the degree of correlation between elements of encouragement important for school education. Actions of encouragement in school education are:

1. Encouraging metacognition

2. Subsidiaries

3. Directing behaviour by the help of examples

4. Freedom of personality

The application of the measures of encouragement by itself needs to be logically linked to the behaviour which we want to approve of, compliment on or reward. The means that we apply the need to match the content of the behaviour or the activities we encourage.

Just as any other motivational basis of behaviour, the application of the means of encouragement has to be appropriate. In addition, the repeated use of the same means can lead to decreasing its efficacy. So, educational actions have to be appropriate for the pupil and his/her experience, which can be stimulating for further behaviour or activities of the pupil. It is desirable to use different kinds of encouragement and allow pupils to suggest their own ways of encouragement.

A prosocially competent teacher will develop the prosocial competencies of his/her pupils, such as: open communication, respecting children's feelings, establishing authority and trust, using positive terms to describe children's characters, improved control of impulses, recognising individual differences, using basic rules as guidance on behaviour, increasing social skills, addressing common sense. By supporting his/her pupils, a 
socially competent teacher encourages tolerance to other religions and nations, stimulates respect for differences, encourages a positive feeling of belonging to a civilised culture. As important functions of the teacher in this area, we should point out the functions of evaluating the state of interpersonal relationships in the collective of the pupils he/she works with and using that evaluation as a basis for choosing appropriate educational strategies to apply and develop in order to support pupils. In this way, the teacher gives children an opportunity and help to develop productive intergroup relationships but also acquire social competences, which they will adopt as their own models of behaviour in time (Suzić, 2001). Understanding other people and groups and interpreting group emotional vibrations and power relations are competences which deserve a special treatment since it is often these kinds of reasoning that serve as a basis for taking a necessary action. Educational models should be based on timely and successful guidance of one's groups as well as acquiring and developing this kind of competence. The responsible behaviour of pupils enables teachers to direct their efforts more to teaching than controlling and managing behaviour in the classroom.

It stands to reason to assume that pupils will learn more and better in these circumstances. Besides, there are some indications that the characteristics of pupils can affect the nature of the teacher-pupil interaction. Teachers behave in a more positive way to pupils who are cooperative than to pupils who behave disruptively. Negatively valued pupils seldom interact with teachers; therefore, the teacher's preference of pupils can, at least to some extent, explain the importance of the relationship between pupils' prosocial behaviour and their school achievement.

A great number of papers have studied the effects of negative social behaviour in comparison with positive one, just as there are a number of papers that deal with the relationship between different aspects of pupils' positive social behaviour and school achievement. Thus, for example, a connection between academic success, on one hand, and empathic behaviour (Feshbach \& Feshbach, 1987), prosocial interaction with peers (Green et al., 1980), prosocial behaviour (Wentzel, 1993; Caprara et al., 2000), peer relationships (Estell et al., 2002), social competences (Bursuck \& Asher, 1986; Wentzel, 1991), on the other, have been studied. Where more complex phenomena (social competence, peer relationship, quality of friendship) are studied, prosocial behaviour makes one of the examined variables. The research on prosocial behaviour is often part of the studies which deal with socio-affective factors of school achievement.

\section{METHOD \\ Research Objectives}

Cognitive: This study aimed to examine teachers' attitudes to the role of the teacher manifest in the encouragement of prosocial behaviour of the young. 
Pragmatic: Searching for the structure of the attitude, we wanted to diagnose the current state of the variables which determined the current educational procedures that teachers use to encourage prosocial behavior.

\section{General Research Hypothesis}

It was hypothesized that teachers understood the role of the teachers as a motivator of prosocial behaviour for moral pedagogy and the connection between prosocial behaviour and the academic achievement.

\section{Research Sample}

The sample included 385 secondary school teachers of comprehensive schools in Serbia. The sample included 146 female teachers, while there were 239 male teachers. The survey was conducted on the territory of Rasina District, more specifically in Kruševac, Aleksandrovac, Ćićevac, Varvarin and Trstenik. The sample was not evenly matched by gender nor was it representative of the entire population of teachers, but it was important regarding its size; therefore, some generalizations are possible but only within the group that made up the sample.

\section{Procedure}

In line with the examined problem and used research methods, we used corresponding statistical procedures which would enable the presentation of the obtained data and their analysis. The statistical analysis were used: descriptive statistics, factor analysis as a form of multivariate data processing by method - categorical principle components analysis, instrument reliability (Crombach Alpha), variant analysis (ANOVA) to determine differences among variables, Bartlett's test and the $\chi^{2}$ (chisquared test).

\section{Variables of the Study}

In our study we isolated age and years of service as independent variables. The number of respondents based on their years of service: up to 10 years of service - $19 \%$, up to 20 years of service - $39 \%$, up to 30 years $24 \%$, over 30 years- $18 \%$.

The number of respondents based on their age: between 18 and 30, a total of $18 \%$, between 31 and 45 , a total of $28 \%$, between 46 and 60 a total of $32 \%$, over 60 years old - a total of $22 \%$.

\section{Research Instruments}

In this study the following instruments were used:

- The PPPA-N evaluation scale - encouraging prosocial behaviour in adolescents (for teachers). The validity of the data was checked by the Kaiser-Meyer-Olkin (KMO) test, whose values of 0.725 
indicated that the data were adequate for the application of this technique.

- A questionnaire made for this study: I Encouraging prosocial behaviour; II The efficacy of the pedagogical methods and educational procedures for the prosocial development; III The role and influence of the teacher on the encouragement of prosocial development and behaviour; IV Carrying out the activities aiming at the encouragement of prosocial behaviour hidden curriculum (Jevtić, 2017).

\section{RESULTS AND DISCUSSION OF RESEARCH}

Regarding the nature of the problem we dealt with, our subject and objectives of the study, we applied a statistical technique - Factor analysis.

In order to compress variables of the PPPA-N scale for teachers and, consequently, apply the statistical technique factor analysis, the validity of the data was first examined by the Kaiser-Meyer-Olkin (KMO) test (Table 1).

Table 1. KMO and Bartlett's tests on the sample of teachers

\begin{tabular}{lcc}
\hline & Kaiser-Meyer-Olkin Measure of & .725 \\
& Sampling Adequacy. & \\
\hline Bartlett'sTest of Sphericity & Approx. Chi-Square & 1758.47 \\
& Df & 739 \\
& Sig. & .000 \\
\hline
\end{tabular}

Table 1. shows the examined validity of the data obtained by the PPPA-N scale for teachers. The PPPA-N scale consisted of 25 items which examined the attitudes of teachers towards the procedures they applied to encourage prosocial behaviour in pupils. The validity of the data was checked by the Kaiser-Meyer-Olkin (KMO) test, whose value of 0.72 shows that the data were valid for the application of this technique. To control the interrelatedness of the factors, we applied the orthogonal rotation, varimax with Kaiser normalisation.

The results obtained by the Kaiser-Meyer-Olkin (KMO) test showed statistical significance $(\mathrm{Sg}=0.00)$ smaller than 0.05 .

Table 2. Factors for teachers obtained by the PPPA-N scale

\begin{tabular}{|c|c|c|c|c|c|c|c|c|c|}
\hline \multicolumn{7}{|c|}{ Loadings } & \multicolumn{3}{|c|}{ Loadings } \\
\hline & Total & $\begin{array}{c}\% \text { of } \\
\text { Variance }\end{array}$ & $\begin{array}{c}\text { Cumulative } \\
\%\end{array}$ & Total & $\begin{array}{c}\% \text { of } \\
\text { Variance }\end{array}$ & $\begin{array}{c}\text { Cumulative } \\
\%\end{array}$ & Total & $\begin{array}{c}\% \text { of } \\
\text { Variance }\end{array}$ & $\begin{array}{c}\text { Cumulative } \\
\%\end{array}$ \\
\hline 1 & 12.624 & 31.732 & 32.734 & 12.624 & 31.732 & 32.734 & 7.609 & 19.125 & 14.936 \\
\hline 2 & 2.614 & 6.385 & 38.256 & 2.614 & 6.385 & 38.256 & 5.462 & 12.621 & 29.854 \\
\hline 3 & 2.206 & 5.920 & 44.149 & 2.206 & 5.920 & 44.149 & 4.439 & 10.191 & 42.183 \\
\hline
\end{tabular}


Factor analysis (Table 2) showed that three factors from the PPPA-N questionnaire for teachers stood out prominent with $42.18 \%$ of the explained variance.

The first factor that stood out explained $19.12 \%$ of the variance, which referred to the nourishing of tolerance and solidarity among pupils, insistence on the respect of differences among pupils, expressing positive and optimistic attitudes to pupils, encouraging the sense of justice and peer communication, praising pupils. The similarity of results compared to the study by (Jevtić, 2017) indicates that the items included in this first factor named focus of the teacher on encouraging prosocial behaviour referred to the efforts and engagement of the teachers directed at creating adequate psycho-social atmosphere in class, which resulted from the efforts of the teacher to create relationships characterized by friendly and cooperative relationships, relationships of mutual trust and respect, dominated by the respect for individual differences. This factor also indicated the engagement of the teachers directed at raising peer communication and the sociometric status of pupils to a higher level in quality. The items included in this factor showed that praise was the dominant educational measure that teachers applied in the area of encouraging prosocial behaviour in adolescents in secondary schools. The second factor that stood out explained $12.62 \%$ of the variance. The items covered by this factor were named as follows: aspiration of teacherstowards a partnership relationship, respect, and honor of the students' personality.

"It turned out that teachers tried to act as role models to their pupils by acting in a prosocial way in their work and their relationship with pupils, coworkers and other people, opting for respecting pupils and their rights and cooperating with them. This factor also indicated that teachers believed in the necessity of building a relationship of empathy with their pupils, since, on one hand, putting oneself into their psychological state would create a higher level of understanding and trust both in the teacher-pupil relationship and in the pupil-pupil relationship, while, on the other hand, it would also contribute to the development of social skills of pupils and improvement of their social relationships.

The third factor which stood out explained $10.19 \%$ of the variance. It referred to pupils' displaying socially competent behaviour, building better interpersonal relationships as well as applying different types of learning (learning by model, verbal prescription) for the sake of achieving academic success. The items included in this factor named focus on school success and achievement showed a similarity in teachers' answers: they believed that prosocial behaviour had to be promoted by the dominant ways of encouragement, such as learning by model and verbal prescription. They also indicated that teachers agreed that the academic success of pupils was possible only if they had developed social skills and built correct and meaningful relations with others, i.e. if pupils had built and developed prosocial behaviour which they would apply in the relationships with their teachers, other pupils and other people. 
To determine the connection as well as the (positive or negative) relationship between these factors, the Spearman correlation coefficient which measures the degree of interrelatedness of two ordinal variables was used" (Jevtić, 2017, p. 41).

The obtained results did not come up to our expectations, but they could be a consequence of the dominance of the educational dimension in this school since a comprehensive secondary school emphasized the acquisition of knowledge and preparation of pupils for university, whereas the other, educational, dimension was neglected and the development of social competences and encouragement of positive social behaviour were marginalized. On the other hand, teachers perception is that the ambition and focus of pupils on personal success and achievement in surveyed schools could have negative repercussions on pupils' openness to others, helping and empathy since it was our hypothesis that these schools developed a competitive atmosphere which by itself was not compatible with the encouragement of the positive patterns of behaviour. Although the respondents for (Jevtic, 2017) and our study were from different geographical areas (Western and Central Serbia), the survey results of (Jevtic, 2017) and our study, as established by the teachers showed that there was no connection at the level of statistical significance between, on one hand, the prosocial behaviour of pupils operationalised through: social response, active helping, sensitivity to others, openness to others and cooperation with teachers and, on the other hand, teachers' focus on encouraging prosocial behaviour and pupils' school success and achievement. The interrelatedness of pupils' empathic sensitivity and teachers' focus on the application of the procedures which would build the empathic relationship and cooperation between pupils could be a consequence of identifying the prosocial procedures and activities of teachers in similar situations, which were connected with verbal prescription regarding the respect of prosocial norms, which teachers insisted on in their work. The conception of a curriculum which emphasises prosocial values and norms is most certainly a humanistic curriculum. Švec (1997) presented a conception of a humanistically oriented curriculum which positively influences the prosocial development of pupils, which is also confirmed by our results which are in accordance with the humanistic conception.

Another statistically significant interrelatedness at the level of significance 0.05 was the connection of the negative direction of pupils' openness to others and teachers' focus on developing cooperation, openness and empathy in pupils. This actually proved the inverse proportion of the obtained factors, i.e. that the teacher's focus on developing cooperation, empathy and openness to others in pupils negatively influenced pupils' openness to others regarding their availability and openness when it was necessary to give help to those who needed it. The inverse proportion of these factors could be explained by inadequate activities that teachers applied in order to encourage pupils' openness and availability to others. 
Namely, teachers' lack of information on the axiological dimension the value that prosocial behaviour had primarily on the social development and functioning of the young, staying only at the verbal level of what should be done without an immediate application of what was said as well as an incorrect choice and application of teaching methods, procedures and types of learning were consequences of this negative correlation. The distribution of the responses to the factors obtained by the PPPA-N scale for teachers in (Jevtić, 2017) research and our research which used a common instrument revealed the order of the obtained factors for teachers: focus on encouraging prosocial behaviour, focus on cooperation, openness and empathy as well as focus on pupils' school success and achievement. It was demonstrated that among the factors obtained by factor analysis the best distributed factor was the one named focus on encouraging prosocial behaviour $(\mathrm{SD}=9.615)$ in research (Jevtić, 2017), and ( $\mathrm{SD}=9.314)$ in our research, which consisted of the items that described teachers' engagement in applying verbal prescription in order to respect prosocial norms, nurture tolerance, solidarity and differences among pupils, nurture a sense of justice in pupils, build a positive attitude to school and education in general, and encourage quality communication not only between the teacher and the pupil but also between peers.

One place behind was the factor focus on school success and achievement with significant distribution $(\mathrm{SD}=8.198)$ (Jevtić, 2017), and $(\mathrm{SD}=8.197)$ our results, which referred to the behaviour of the teacher which makes him/her a role model to pupils in prosocial actions, the inclusion of school professional services in encouraging prosocial behaviour and nurturing communication and cooperation with others, the choice of teaching materials which provided support in acquiring and adopting necessary knowledge and skills, and building socially desirable attitudes. The factor with the least expressed distribution obtained through factor analysis identical in both studies $(\mathrm{SD}=5.368)$ was focus on cooperation, openness and empathy, which was based on the teacher's focus on encouraging social skills, nurturing the need to do sports and applying learning by model as a dominant way of nurturing peer communication and adopting prosocial patterns of behaviour.

To prove whether the instrument had met the parametric criteria, it was necessary to check the normality of the distribution curve. The check of this curve was done by the Kolmorgorov-Smirnov test, while the ShapiroWilk test would show if distribution could also met stricter criteria of normality. The normality tests were defined by the items: prosocial behaviour and pupils' school success, methods and techniques used for encouraging prosocial behaviour, pupils' prosocial behaviour and the influence of peer interaction in class, prosocial behaviour and the teacher. The values of the Kolmorgorov-Smirnov and Shapiro-Wilk tests showed that the distribution of results was at the level of significance $\mathrm{p}=0.001$ for all 25 claims. This test 
revealed that our results had met the criteria of normality of the distribution curve.

The results of the study based on the teachers' opinion obtained from a sample of 385 secondary school teachers in Serbia showed that prosocial behaviour represented an independent predictor of success in relation with school marks. The results showed that prosocial behaviour had a direct impact on the teacher's evaluation of academic behaviour (interest to learn, independence in work etc.), which, on other hand, affected the success expressed by school marks. However, it is interesting that this study did not confirm that pupils' prosocial behaviour significantly affected the teacher's preferences, i.e. that the relationship of positive social behaviour and school success could be explained by the teacher's preferences. Positive (and negative) behaviour was a stronger predictor of school marks than scores in standardized tests, which should come as no surprise since school marks were more closely connected with the social context in which learning and the evaluation of achievement took place. Although it cannot be denied that school achievement affects prosocial behaviour in class, the reverse direction is more likely, to which the finding that social behaviour is independent of the scores in standardized tests (Wentzel, 1991) also points. Thus, we concluded that teachers highly valued the items which were connected with the role of prosocial orientation in achieving school success through various curricular and extracurricular activities, thus believing that success that children had at school both directly and indirectly affected prosocial behaviour, higher motivation, engagement of pupils in and out of class.

This finding is in line with the findings of Bandura and associates (Bandura et al., 1996), who carried out a broader study trying to analyse the psychosocial mediators of school success and the role of prosocial behaviour.

One of our sub-hypothesis and research (Jevtić, 2017) referred to teachers' perception of the connection between pupils' prosocial behaviour and the influence of peer interaction in class, the influence of cooperation and commitment as well as the undesirable forms of behaviour (physical abuse, offences, humiliating others...). We expected that the results would confirm the findings that supported the view about the connection between peer interaction and pupils' prosocial behaviour. Our study and study (Jevtić, 2017) gave identical answers of the surveyed teachers' opinion from two different districts in Serbia, which confirms the compliance of teachers' views on encouragement of pro-social behavior: teachers showed agreement with the items which referred to cooperation, cooperative and helping behaviour, but, on the other hand, they mostly disagreed with the items that referred to the undesirable forms of behaviour (physical abuse, offenses, humiliating others...). Our study showed that teachers highly valued cooperative, helping behaviour, cooperation and nurturing care and understanding for others. They believed that children had to be accepted by their peers and that it was the only way in which they would manage to exhibit prosocial forms of behaviour at school. Children who were accepted by their peers and who 
exhibited prosocial, cooperative and responsible forms of behaviour at school most frequently had great success at school, while socially rejected and aggressive children often had low achievements at school.

Examining teachers' attitudes to whether they themselves affected building pupils' social competences by applying various methods, we wanted teachers to evaluate their own social behaviour and their relationship with pupils in class but also express their own opinion and evaluation of their own knowledge, skills and competences to participate in building socially competent pupils and encourage the development of prosocial behaviour by using various methods of teaching and work in class, interacting with pupils and giving a personal example.

It turned out that the function of evaluating the state of interpersonal relationships in the collective of pupils/ children the teacher worked with, on one hand, and of using the results of that evaluation to develop or apply corresponding educational strategies in order to support pupils, on the other, were seen as significant functions of teachers in this area.

The teacher's role in creating a good atmosphere in the classroom could be fulfilled through encouraging friendship among pupils. This was supported by the finding about a considerable connection between the classroom atmosphere and of the teacher's contribution to developing friendship $(\mathrm{C}=0.45)$, which means that the class atmosphere was more pleasant if the teacher considerably contributed to the development of friendship among pupils. Developing friendship, and thus creating a pleasant classroom atmosphere, was observable in teachers who expressed tolerance and understanding for pupils and encouraged them to mutual cooperation and solidarity, unlike teachers who encouraged competition and the pursuit of prestige in pupils.

Starting from the research results of (Jevtic, 2017) and based on our results, it can be concluded that among teachers of different age there were certain differences regarding the question of perceiving prosocial behaviour and school achievement and their interrelatedness. Namely, it was noticed that older teachers expressed a higher degree of agreement with some items than their younger fellow workers. Older teachers showed a higher degree of agreement with the statements that boys were less emphatic than girls and that girls had greater academic success than boys. The results of examining the differences at the level of the perception of the interrelatedness of prosocial behaviour and school achievement among teachers of different age showed that younger teachers valued this form of behaviour and school achievement differently, even more positively (Sakač, 2008; Omerović, Džaferagić-Franca, 2012). Slightly lower values were recorded in older teachers. However, the results showed that there was no statistically significant difference in the attitudes about prosocial behaviour between older and younger teachers. On the other hand, attitudes about school achievement were statistically significant at the level of 0.01 . 
Statistical cross-referencing of dependent variables and the independent variable years of service showed that there was no difference in distribution among teachers having different working experience within these dependent variables. Teachers of different working experience equally agreed with the statements that prosocial behaviour was exhibited by secondary school pupils and that such a behaviour considerably contributed to their school achievement. Also, teachers were almost unanimous regarding the relationship among pupils and interaction in class, but they also pointed out that it was necessary to respect one's own emotions and needs when working with pupils. Clearly, a number of teachers who worked at school longer believed that some measures which gave the child greater freedom were inappropriate and that children had to be controlled without necessarily giving them too much freedom. On the other hand, there were some teachers of shorter work experience who also approved of applying harsher measures aiming at encouraging children to behave adequately. Most teachers achieved a high degree of agreement not only on the topic of prosocial behavior but also on their expectation of the school achievement of secondary school pupils.

An important element of encouraging prosocial behaviour was adopting prosocial values. Teachers directed pupils' attention to prosocial behaviour that had been exhibited in class or at school and they talked with pupils about the values relevant for the specific form of prosocial behaviour. In this way, teachers helped pupils to understand and adopt prosocial values and to exhibit prosocial behaviour (Jevtić, 2017).

To reduce prejudice and social distance between members of some groups as sources of conflict and obstacles to prosocial behaviour at school, it was important to encourage positive attitudes to differences and to contribute to better relationships among pupils of different sex, social background, abilities, ethnicity. The obtained value of the chi square test was higher in comparison with the limits (for df 3 at the level of statistical significance, the value of hi square was 11.341), which means that there was a statistically significant difference in teachers' responses. Thus, the number of teachers who encouraged the positive attitudes of pupils regarding differences in gender, social background, ethnicity, abilities was more significant than the number of those who did not or were indecisive.

An important motive for prosocial behaviour was social responsibility, which included a feeling of personal responsibility for one's own acts and their impact on others. Induction, as a form of reasoning, is particularly important for the development of prosocial behaviour. Induction means that children are given an explanation of the consequences of their behaviour on other people. The analysis of the obtained results showed that a statistically significant number of teachers were focused on the verbal way of encouraging prosocial behaviour (through conversation on values, tolerance, verbal prescription etc). Statistically, we did not obtain significant differences regarding the use of films, television, examples from literature and the press. 
In the investigation of the auxiliary hypothesis whose function was to test the overall trends which could not be used to determine a direct connection between teachers and pupils, the results have shown an overall trend on a larger sample, as well as the covariations in teachers' activities for the encouragement of prosocial behaviour and prosocial behaviour of pupils measured through six aspects. This speaks in favour of the quite individual, sporadic attempts of teachers and specific methods to encourage prosocial behaviour in pupils, in the sense that teachers do not apply similar criteria but that they are different from teacher to teacher.

Finally, judging from the obtained results we can assume that the general hypothesis which assumed the connection of procedures which teachers used to encourage prosocial behaviour in adolescents and the efficacy of their application in the teaching process was partly confirmed.

\section{CONCLUSION}

Social pedagogy is a modern pedagogical discipline in the process of development which studies the problems and needs of the young. The segment of the prosocial behaviour of the young, which is the subject matter of social pedagogy, is a phenomenon to which we need to pay due attention and show how significant it is considering the role it has in the process of the personality formation of the young. This paper made a step forward towards determining the role of some (school) factors in the encouragement of prosocial orientation in adolescents. To give an adequate answer to the problem mentioned above, first we gave an extensive review of theoretical findings of domestic and world researchers and then we presented a study conducted in Serbian secondary schools.

Teachers could serve as role models, as moral persons who demonstrated a high level of respect and responsibility in their behaviour in and out of class. They could model moral care, interest and moral reasoning in their pupils through their own reaction to morally significant events in and out of school. Fair teachers who adopted altruistic values and teachers who showed understanding for pupils and who encouraged them to mutual cooperation, solidarity and tolerance contributed to the prosocial development of the young. The results of our study showed that a statistically significant number of teachers perceived setting an example as the most efficient way of encouraging prosocial behaviour and that they tried to a model of prosocial behaviour by giving a personal example. These results were highly significant because they indicated a developed consciousness and knowledge of teachers regarding the influence of the role model on pupils' behaviour.

The activities (Jevtić, 2017) which teachers used to encourage prosocial behaviour in pupils referred to strengthening intergroup relationships and solving conflicts among pupils since it is well known that harmonious peer relations are the basis for the development of prosocial 
behaviour. However, our results showed that teachers did not deal with solving peer conflicts and problems. These data do not support the finding that teachers could affect prosocial behaviour through the influence on peer relationships.

Judging from the results of the study based on the perception of teachers from Western and Central Serbia (Jevtić, 2017) it can be assumed that teachers believed that there were two groups of pupils which exhibited statistically significantly difference at the level of prosocial behaviour and school achievement. The first group was made up of pupils who did not exhibit prosocial behaviour and did not have significant success at school, while the other group was made up of pupils who behaved prosocially towards others. In addition, if we bear in mind the results of the opinions and attitudes of teachers on the distribution of pupils of different genders within the isolated categories of roles, i.e. the significance of gender differences in different roles for prosocial behaviour, it is possible to complete the description of these two groups of pupils with the following statement: pupils who were prosocial were considerably connected with the school and achieved higher academic success, while pupils who did not behave prosocially to others were mostly recruited from the category of pupils of the female gender.

This paper seems to have come to certain relevant scientific findings. Studying this problem, some dilemmas which can be the starting point of future studies can be identified: 1. Is high academic success at the end of the first term and at the end of the school year respectively really a predictor of the prosocial behaviour of the young or are such pupils egotistically oriented and focused on personal success, i.e. could it be that pupils of lower academic achievements are more open to providing help to others, cooperation and solidarity according to teachers?; 2. Do the work experience and educational profile of the teacher determine the procedures and activities by which he/she is guided in encouraging prosocial behaviour in pupils; 3. Are the procedures and activities which guide teachers in their encouraging prosocial behaviour in pupils different among teachers who have different degrees in education.

We assumed that the professional competence of teachers in their work with pupils in the area of the encouragement of prosocial behaviour is conceived in a similar way by didactic-methodical procedures such as cooperative learning, observational learning, verbal prescription, giving positive examples of prosocial activities, and the like; however, it has been shown that this trend is not based in practice but that it comes down to the individual efforts of teachers to develop and encourage prosocial behaviour in their pupils.

Finally, we see that the results of our study and study (Jevtić, 2017) pointed to some pedagogical implications: the reform of the educational system in Serbia, especially of secondary school education, which has been in a pressing need of changes directed at answering to the needs and interests 
of pupils; a change of educational objectives and tasks in the sense that we should take greater care of individual pupils and the development of those values which contribute to improving personal relationships and quality of pupils' life; establishing a continuity between all levels of the educational system and raising cooperation with parents to a higher level; continuous support of educational professional services to teachers in the area of raising their interest in acquiring and applying strategies and skills directed at educating prosocially oriented personalities and improving the quality of their work by implementing the programs which have proved extremely successful in the field of encouraging the prosocial behaviour of adolescents in secondary schools of other countries.

\section{REFERENCES}

Bandura, A. et al. (1996). Multifaced impact of self-efficacy beliefs on academic functioning. Child Development, 67, 1206-1222.

Batson, D. (2008). Empathy-Induced Altruistic Motivation. Departmen of Psihology. University of Kansas.

Batson, D. \& Shaw, L. (1991). Evidence for Altruism: Toward a Pluralism of Prosocial Motives. Psyhological Inquiry, 2, 107-122.

Bursuck, W. D. \& Asher, S. R. (1986): The relationship between social competence andachievement in elementary school children. Journal of Clinical Psychology, 15, 41-49.

Caprara, G.V. et al: (2000). Prosocial foundations of children's academic achievement. Psychological Science, 11, No. 4, 302-306.

Chen, X., Rubin, K.H. \& Li, D. (1997). Relations between academic achievement and social adjustment: evidence from Chinese children. Developmental Psychology, 33, No.3, 518-525.

De Waal, F. B. (2008). Putting the altruism back into altruism: The evolution of empathy. Annual Review of Psychology, 59, 279-300.

Eisenberg, N. \& Mussen, P.H. (1989). The roots of prosocial behavior in children. Cambridge: Cambridge University Press.

Eisenberg, N.,\&Valiente,C. (2002). Parenting and children's prosocial and moral development. In M. H. Bornstein (Ed.), Handbook of parenting: 5. Practical issues in parenting (2nd ed., 111-142).

Estell, D.B. et al. (2002). Social relations and academic achievement in inner-city earl elementary classrooms. International Journal of Behavioral Development, 26, No. 6, 518-528.

Feshbach, N.D. \& Feshbach, S. (1987). Affective processes and academic achievement. Child Development, 58, No. 3, 1335-1347.

Green, K.D. et al. (1980). An assessment of the relationship among measures of children's social competence and children's academic achievement. Child Development, 51, No. 4, 1149-1156.

Grusec, J. E., Davidov, M.,\& Lundell, L. (2002). Prosocial and helping behavior: Blackwell handbooks of developmental psychology. In Hart \& Smith (Eds.), Blackwell handbook of childhood social development, 457-474.

Hastings, P.D., Utendale, W.,\& Sullivan, C. (2007). The socialization of prosocial development. In Grusec, \& Hastings (Eds.), Handbook of Socialization, 638-664.

Jevtić, B. (2015). Pedagogija moralnosti [Pedagogy of Morality]. Niš: Filozofski fakultet.

Jevtić, B. (2017). The attitude of teachers towards prosocial behavior and academic achievement in Serbia. Problems of Education in the $21^{\text {st }}$ century, 75, No.1, 34-54. 
Joksimović, S. \& Vasović, M. (1990). Psychological foundations of humanity. Belgrade: Institute for Educational Research and education.Joksimović, S. (1993). Dimensions and indicators of prosocial behavior. Proceedings of the Institute for Educational Research. 25, 9-24.

Kakavulis, A. (1997). Altruism in early childhood: how parents see the altruistic behavior of their children. Education and altruism. Institute for Educational Research, 237-252.

Knafo, A. \& Plomin, R. (2006). Prosocial Behavior From Early to Middle Childhood: Genetic and Environmental Influences on Stability and Change. Developmental Psychology. 42, No. 5, 771-786.

Lobocki. M. (1997). Altruism as the main aim of family education. Education and altruism. Institute for Educational Research, 112-119.

McDonald, N. M., \& Messinger, D. S. (2010). The Development of Empathy: How, When, and. Why. USA: Department of Psychology, University of Miami.

Omerović, M., Džaferagić-Franca A. (2012). Aktivno učenje u osnovnoj školi [Active Learning in Primary Schools]. Metodički obzori, 7(1), 167-181.

Rotheram, M.J. (1987). Children's social and academic competence. Journal of Educational Research, 80, No. 4, 206-211.

Sakač, M. (2008). Neki psihološki činioci školskog postignuća [Some Psychological Component of School Achievement]. Norma, 13(3), 29-36.

Staub, E. (1978). Positive social behavior and morality: social and personal influence. New York: Academic Press.

Suzić, N. (2001). The emotional dimension of motivation to continue. Banja Luka: Faculty of Philosophy.

Švec, Š. (1997). Humanistički orijentisano obrazovanje kao model za razvoj altruizma [Humanistically Oriented Education as a Model for the Development of Altruism]. Vaspitanje i altruizam, 120-130.

Twenge, J. et al. (2007). Social Exclusion Decreases Prosocial Behavior. Journal of Personality and Social Psychology, 92, No. 1, 56-66.

Zahn-Waxler, C.,\& Kochanska, G. (1990). The origins of guilt: Current theory and research in motivation. In R. A. Thompson (Ed.), Nebraska symposium on motivation: 36. Socioemotional development, 183-258.

Wentzel, K.R. (1991). Relations between social competence and academic achievement in early adolescence. Child Development, 62, 1066-1078.

Wentzel, K. R. (1993). Does being good make the grade? Social behavior and academic competence in middle school. Journal of Educational Psychology, 85, No. 2, 357-364.

Žilínek, M. (1997). Etos a utváranie mravnej identity. Bratislava: IRIS.

\title{
ШКОЛСКИ ПОКАЗАТЕЉИ ПОДСТИЦАЫА ХУМАНИСТИЧКОГ ВАСПИТАЫА АДОЛЕСЦЕНАТА
}

\author{
Бисера Јевтић, Марија Јовановић \\ Универзитет у Нишу, Филозофски факултет, Департман за педагогију, Ниш, \\ Србија \\ Резиме
}

Без обзира на значај који се огледа у формирању личности адолесцената са највишим људским квалитетима и моралним вредностима, хуманистичко васпитање и просоцијално понашање још увек је непознаница како у научним круговима тако и 
међу представницима васпитно-образовног процеса. Посматрајући тренутни друштвени контекст у коме живимо, можемо уочити својеврсни парадокс. Наиме, са једне стране, бројне промене које прате једно транзиционо друштво као што је наше прави поремећен систем вредности, кризу морала, агресивност, што може бити препрека развијању и подстицању позитивног социјалног понашања младих. Сa друге стране, хуманистичко васпитање и позитивни облици понашања као што је просоцијално понашање, алтруизам, емпатија најпотребнији су за развој и формирање свестране, самосталне, стваралачке, функционалне личности.

Испитујући понашање и ставове наставника о подстицању хуманог просоцијалног понашања, установили смо да је у испитиваним школама на територији Расинског округа повезаност међу добијеним факторима позитивног или негативног смера, док у неким школама повезаност просоцијалних поступака наставника са просоцијалним понашањем ученика није пронађена. Добијени резултати показују да рад и деловање наставника на подстицању просоцијалног понашања ученика у средњим школама само једним делом афирмише просоцијално понашање, што се може објаснити недовољном ефикасношћу у раду, недовољном сутручном оспособљеношћу, али и инертношћу према савременим методама и облицима рада којима се може адекватно одговорити на потребе и интересовања ученика. Поред наведених, на неефиксно подстицање просоцијалног подстицања утиче и непосвећивање пажње и времена просоцијалном понашању услед оптерећености наставним планом и програмом и решавањем акутних дисруптивних понашања у школи. На нешто лошију ефикасност у подстицању просоцијалног понашања ученика утиче и сама сложеност овог проблема јер нам добијени резултати указују на то да просоцијално понашање адолесцената зависи од многих фактора, а не само од агенаса социјализације као што је школа, што се потврђује и кроз теоријске импликације у раду.

Наведене теоријске импликације које говоре о томе да се просоцијално понашање на основу процене наставника повећава са узрастом такође смо проверили спроведеним истраживањем. Показало се да се просоцијално понашање делимично повећава са узрастом јер се у појединим сегментима понашања повећава, а у појединим остаје непромењено. Такође, у погледу реципроцитета који постоји у односу просоцијално понашање - академски успех, на полугођу и на крају школске године спроведено истраживање је оповргло наше претпоставке да је просоцијално понашање показатељ који предвиђа висока академска постигнућа, односно да је високо академско постигнуће показатељ који предвића манифестације просоцијалног понашања. Показало се да су манифестацији просоцијалног понашања склони ученици са нижим академским постигнућем, што се може објаснити чињеницом да су ученици нижих образовних постигнућа мање усмерени на учење и стицање формалних знања, те показују већи сензибилитет за помоћ другима који су у стању потребе.

Бавећи се овом проблематиком, чињеница је да смо овим радом дошли до извесних релевантних научних сазнања. Уједно, наметнуле су се и одређене дилеме које могу бити окосница нових хуманистичких истраживања. 